Energy Systems Environmental Restoration Program ORNL Environmental Restoration Program

\title{
Removal Action Plan for Corehole 8 in Waste Area Grouping 1 at Oak Ridge National Laboratory, Oak Ridge, Tennessee
}

Date Issued-November 1994

\author{
Prepared by \\ Foster Wheeler Environmental Corporation \\ Oak Ridge, Tennessee 37830 \\ under Contract DE-AC05-91OR21928
}

Prepared for

U.S. Department of Energy

Office of Environmental Restoration and Waste Management under budget and reporting code EW 20

Environmental Restoration and Waste Management Programs

Oak Ridge National Laboratory

Oak Ridge, Tennessee 37831

managed by

MARTIN MARIETTA ENERGY SYSTEMS, INC.

for the

U.S. DEPARTMENT OF ENERGY

under contract DE-AC05-84OR21400 


\section{DISCLAIMER}

This report was prepared as an account of work sponsored by an agency of the United States Government. Neither the United States Government nor any agency thereof, nor any of their employees, make any warranty, express or implied, or assumes any legal liability or responsibility for the accuracy, completeness, or usefulness of any information, apparatus, product, or process disclosed, or represents that its use would not infringe privately owned rights. Reference herein to any specific commercial product, process, or service by trade name, trademark, manufacturer, or otherwise does not necessarily constitute or imply its endorsement, recommendation, or favoring by the United States Government or any agency thereof. The views and opinions of authors expressed herein do not necessarily state or reflect those of the United States Government or any agency thereof. 


\section{DISCLAIMER}

Portions of this document may be illegible in electronic image products. Images are produced from the best available original document. 


\section{CONTENTS}

ABBREVIATIONS $\ldots \ldots \ldots \ldots \ldots \ldots \ldots \ldots \ldots \ldots \ldots \ldots \ldots \ldots \ldots \ldots$

EXECUTIVE SUMMARY $\ldots \ldots \ldots \ldots \ldots \ldots \ldots \ldots \ldots \ldots \ldots \ldots \ldots \ldots \ldots \ldots \ldots$ vii

1. INTRODUCTION AND SITE DESCRIPTION $\ldots \ldots \ldots \ldots \ldots \ldots \ldots \ldots$

2. SUMMARY OF SITE CHARACTERIZATION $\ldots \ldots \ldots \ldots \ldots \ldots \ldots \ldots$

2.1 STORM SEWERS $\ldots \ldots \ldots \ldots \ldots \ldots \ldots \ldots \ldots \ldots \ldots \ldots, 4$

2.2 GROUNDWATER $\ldots \ldots \ldots \ldots \ldots \ldots \ldots \ldots \ldots \ldots \ldots \ldots \ldots, 4$

2.3 SOILS $\ldots \ldots \ldots \ldots \ldots \ldots \ldots \ldots \ldots \ldots \ldots \ldots \ldots \ldots \ldots \ldots \ldots, 4$

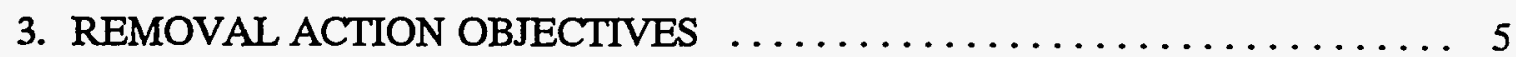

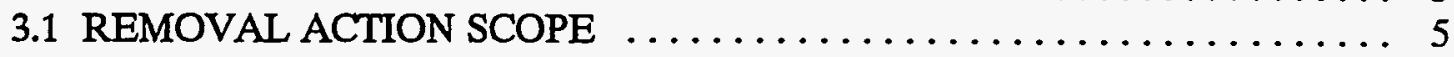

3.2 PROJECT REQUIREMENTS $\ldots \ldots \ldots \ldots \ldots \ldots \ldots \ldots \ldots \ldots \ldots \ldots \ldots \ldots \ldots \ldots \ldots$

4. RESPONSIBILITIES AND METHODS OF ACCOMPLISHMENT $\ldots \ldots \ldots \ldots 7$

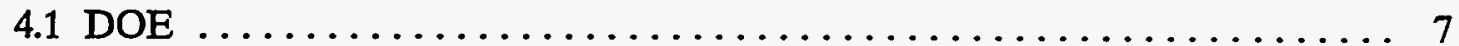

4.2 FOSTER WHEELER $\ldots \ldots \ldots \ldots \ldots \ldots \ldots \ldots \ldots \ldots \ldots \ldots \ldots \ldots \ldots \ldots \ldots$

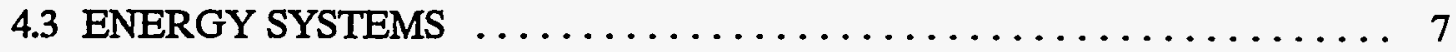

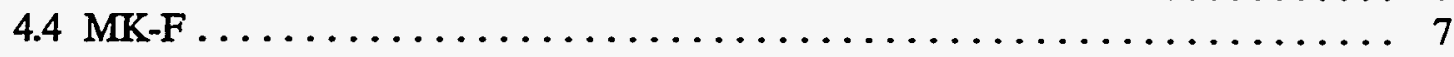

5. OVERVIEW OF REMOVAL ACTION $\ldots \ldots \ldots \ldots \ldots \ldots \ldots \ldots \ldots$

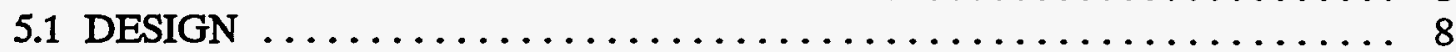

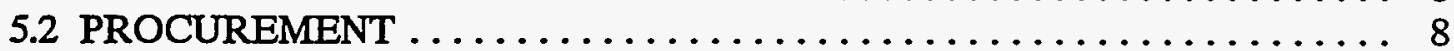

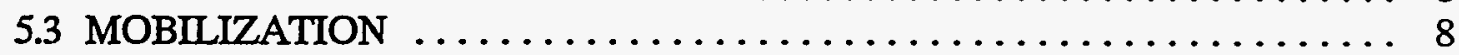

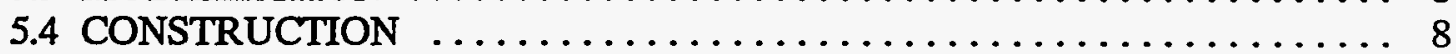

5.5 DECONTAMINATION PROCEDURES $\ldots \ldots \ldots \ldots \ldots \ldots \ldots \ldots \ldots, 10$

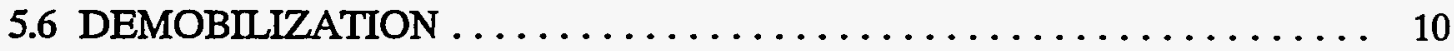

5.7 POSTCONSTRUCTION REPORT $\ldots \ldots \ldots \ldots \ldots \ldots \ldots \ldots \ldots \ldots \ldots \ldots \ldots \ldots \ldots \ldots$

6. BIBLIOGRAPHY $\ldots \ldots \ldots \ldots \ldots \ldots \ldots \ldots \ldots \ldots \ldots \ldots \ldots \ldots \ldots \ldots \ldots \ldots \ldots$

Appendix A: Project Participant/Responsibility Assignment Matrix .......... A-1 



\section{ABBREVIATIONS}

CERCLA

CFR

DOE

Energy Systems

ER

EPA

MK-F

ORNL

ORR

OSHA

RAWP

TDEC

WAG
Comprehensive Environmental Response, Compensation and Liability Act Code of Federal Regulations

U.S. Department of Energy

Martin Marietta Energy Systems, Inc.

Environmental Restoration

U.S. Environmental Protection Agency

MK-Ferguson of Oak Ridge Company

Oak Ridge National Laboratory

Oak Ridge Reservation

Occupational Safety and Health Administration

Removal Action Work Plan

Tennessee Department of Environment and Conservation

Waste Area Grouping 

$-$ 


\section{EXECUTIVE SUMMARY}

The objective of the Waste Area Grouping 1 Corehole 8 Removal Action is to collect strontium-90 contaminated groundwater that is currently being discharged from existing storm drains into First Creek. ${ }^{90} \mathrm{Sr}$ has been identified as a major contributor to potential risk offsite. First Creek contributes about $10 \%$ of the ${ }^{90} \mathrm{Sr}$ contamination detected at White Oak Dam. This Removal Action Work Plan (RAWP) addresses construction of new french drains, gravity piping, and a pressure sewer pipeline to collect and pump the contaminated water to Manhole 24. The contaminated water will then flow through existing pipes to the Process Waste Treatment Plant for treatment.

The proposed scope of work for this project includes the installation of approximately $480 \mathrm{ft}$ of high-density polyethylene gravity piping, with cleanouts, to transport the contaminated water to a proposed pumping station. The contaminated water will then be pumped from the new pump station approximately $1,140 \mathrm{ft}$ through a new force main to Manhole 24. This project will reduce the quantity of ${ }^{90} \mathrm{Sr}$ contaminated groundwater entering First Creek.

This RAWP has been prepared jointly by Martin Marietta Energy Systems, Inc.; MKFerguson of Oak Ridge Company; and Foster Wheeler Environmental Corporation. 


\section{INTRODUCTION AND SITE DESCRIPTION}

The U.S. Department of Energy (DOE) facilities in Oak Ridge, Tennessee, have been in operation since 1943. During this period, radioactive and hazardous wastes have been disposed of at the Oak Ridge National Laboratory (ORNL) on the Oak Ridge Reservation (ORR). Accidental releases of radioactive and hazardous substances have also occurred. Remedial investigations and other environmental investigations in Waste Area Grouping (WAG) 1, located within the main plant area of ORNL, have revealed strontium-90 contamination in the groundwater. In 1991, gross beta contaminated groundwater was detected in bedrock about $50 \mathrm{ft}$ below the surface during the drilling of Corehole 8 . The drilling at Corehole 8 was stopped because of the high levels of gross beta contamination (approximately $500,000 \mathrm{pCi} / \mathrm{l}$ ). The primary source of gross beta contamination was later identified as ${ }^{90} \mathrm{Sr}$. That same year, First Creek was sampled and found to be contaminated with ${ }^{90} \mathrm{Sr}$. Approximately a year after this sampling was completed, a possible connection between the contamination detected at Corehole 8 and in First Creek was hypothesized. A ${ }^{90} \mathrm{Sr}$ plume was thought to be in the groundwater flowing from a location near Corehole 8 along the bedrock surface towards First Creek.

As the groundwater flows toward First Creek, it encounters outfalls from storm sewer systems. The storm sewer systems are not watertight, and groundwater infiltrates and flows through these drains into First Creek. The storm sewer systems serving the western portion of WAG 1 empty into First Creek at Outfalls 341 and 342. The 1991 First Creek sampling results implied that nearly all of the ${ }^{90} \mathrm{Sr}$ entering the creek flowed through, or closely adjacent to, these two outfalls. Some preliminary data also revealed the possibility of ${ }^{90} \mathrm{Sr}$ entering First Creek from groundwater seeps upstream from the outfalls.

Sampling of water at White Oak Dam identified ${ }^{90} \mathrm{Sr}$ as a major contributor to off-site risk to the public and the environment. In an effort to reduce this risk, the sources of ${ }^{90} \mathrm{Sr}$ entering White Oak Creek were identified and their contribution quantified. First Creek contributes approximately $10 \%$ of the ${ }^{90} \mathrm{Sr}$ detected at White Oak Dam.

DOE, the Tennessee Department of Environment and Conservation (TDEC), and the U.S. Environmental Protection Agency (EPA) decided to initiate a non-time-critical removal action to reduce the amount of ${ }^{90} \mathrm{Sr}$ entering First Creek from the western portion of WAG 1 north of Central Avenue and west of First Creek. This removal action is being conducted in accordance with the Comprehensive Environmental Response, Compensation, and Liability Act (CERCLA) process to reduce the off-site risk until a final action can be implemented for this site.

ORNL is located about 7 miles south of the center of Oak Ridge and is one of the three main DOE facilities on the ORR. WAG 1 covers 150 acres of the main plant area within the ORNL security fence. The central portion of the First Creek watershed is located north of Central Avenue, west of Third Street, south of Buildings 2007 and 2008, and east of First Creek. Corehole 8 is about $1,000 \mathrm{ft}$ east of First Creek. First Creek flows from north to south alongside First Street and outside the west security fence and eventually empties into White Oak Creek. The general project location is shown on Figure 1. New french drains will be 


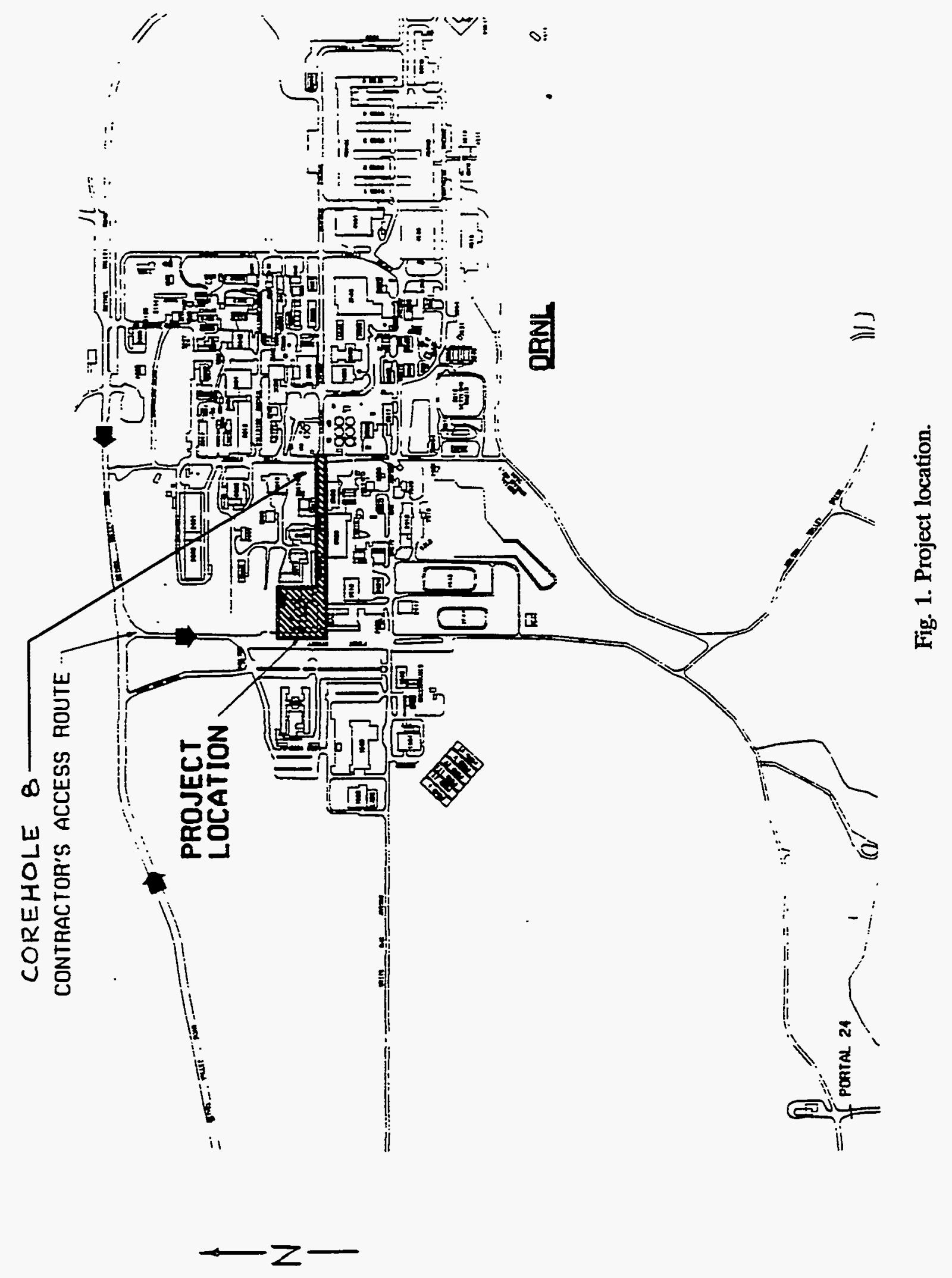


constructed at the two catch basins north of Building 2013 and at the existing 6-in. storm drain, which is near the northwest corner of Building 2016. The new gravity piping will run from new french drains near the two catch basins north of Building 2013 to the new pump station north of Building 2016 and from the new french drain west of Building 2016 to the new pump station. A new gravity pipe will also be installed from the catch basin west of Building 2016 to the 6-in. storm drain adjacent to Building 2016. The force main will run from the pump station to Manhole 24. The contaminated water will flow through existing gravity sewers to the Process Waste Treatment Plant. 


\section{SUMMARY OF SITE CHARACTERIZATION}

\subsection{STORM SEWERS}

Gross beta activity values from water within the storm sewer system leading to Outfalls 341 and 342 were measured once in 1991 and twice during 1994. Gross beta activities throughout the storm sewer system associated with Outfall 341 have ranged between 7000 and $8000 \mathrm{pCi} /$. Gross beta activities in the catch basins north of Building 2013 have ranged from 7290 to $9200 \mathrm{pCi} / 1$.

\subsection{GROUNDWATER}

Laboratory analyses of groundwater samples from wells in the vicinity of this project indicate gross beta activities from 8,200 to $12,900 \mathrm{pCi} / 1$.

\section{SOILS}

Several soil samples were obtained in the vicinity of Building 2013 during Phase I remedial investigations of WAG 1 (BNI 1992). Gross alpha and gross beta activity in shallow soils (less than $6 \mathrm{ft}$ deep) ranged as high as $18 \mathrm{pCi} / \mathrm{g}$ gross alpha and $32 \mathrm{pCi} / \mathrm{g}$ gross beta, which is below the maximum WAG 1 reference (background) values of $56 \mathrm{pCi} / \mathrm{g}$ gross alpha and $34 \mathrm{pCi} / \mathrm{g}$ gross beta. 


\section{REMOVAL ACTION OBJECTIVES}

\subsection{REMOVAL ACTION SCOPE}

The scope of this removal action is to prevent or limit the release of ${ }^{90} \mathrm{Sr}$ into First Creek, which will reduce, in a proportional manner, the release of ${ }^{90} \mathrm{Sr}$ over White Oak Dam. The specific scope and objectives of the proposed action are as follows:

- to follow CERCLA guidance to implement a non-time-critical removal action that intercepts ${ }^{90} \mathrm{Sr}$ contaminated groundwater before it enters First Creek;

- to collect and treat contaminated water where pathway(s) are known and where contaminated water can be easily intercepted;

- to maintain and operate a collection system until it is no longer considered necessary or cost-effective;

- to take a two-phased approach in removing contaminated groundwater influx and, with additional monitoring data, locate and possibly remove additional contaminated groundwater; and

- to monitor the flux of ${ }^{90} \mathrm{Sr}$ into First Creek and from First Creek to White Oak Creek to measure the effectiveness of the removal action in reducing flux and use that data to determine whether or not further action is required.

\subsection{PROJECT REQUIREMENTS}

The project requirements are

- to reduce the ${ }^{90} \mathrm{Sr}$ flux at First Creek from $10 \mathrm{mCi} / \mathrm{month}$ to $3-5 \mathrm{mCi} / \mathrm{month}$;

- to maintain proper storm and groundwater collection, transfer, and discharge capabilities during construction;

- to perform construction in compliance with Code of Federal Regulations (CFR) 29 CFR 1926, Safety and Health Regulations for Construction which includes fire protection requirements;

- to perform construction in compliance with 29 CFR 1910, Occupational Safety and Health Administration standards, which includes 29 CFR 1910.120, Hazardous Waste Operations and Emergency Response (see Appendix A);

- to perform Quality Assurance in compliance with DOE Order 5700.06C;

- to control fugitive dust emissions stemming from construction activities to meet the limits of and comply with TDEC Chapter 1200-4-10-.05; and 
- to control emissions of radionuclides generated from this project (e.g., construction) so as not to exceed the limits delineated in 40 CFR 61.92 and DOE Order 5400.5. 


\section{RESPONSIBILITIES AND METHODS OF ACCOMPLISHMENT}

The design and execution of the removal action will be accomplished with the joint resources of the following participants: DOE; Foster Wheeler Environmental Corporation, architect-engineer; Martin Marietta Energy Systems, Inc., Facilities Manager, and MKFerguson of Oak Ridge Company (MK-F), construction manager/contractor. The latter three participants are under prime contract to DOE. The roles and responsibilities for each participant are summarized in the following sections. A detailed Project Participant/Responsibility Assignment Matrix is also given in Appendix A.

\subsection{DOE}

DOE will furnish overall project management; review and accept Title $\Pi$ (60\% and 90\%) design packages; administer all prime contracts; and direct all aspects of the project, including specific details of work assignments to the various participants. DOE will have the authority to approve all work performed. DOE will also identify the individual who will sign as the generator on all waste manifests. All participants will be under prime contract to DOE or under subcontract to Energy Systems or MK-F with the approval of DOE.

\subsection{FOSTER WHEELER}

Title II engineering design will be performed by Foster Wheeler. Design deliverables will include electronic data and a reproducible hard copy of design drawings, engineering calculations, construction specifications, data sheets, flow diagrams, construction project requirements summaries, cost estimates, a construction schedule, and this RAWP.

\subsection{ENERGY SYSTEMS}

Energy Systems is responsible for integration of project activities into the appropriate Environmental Restoration (ER) management and operating contractor functional systems. This includes coordination with Waste Management personnel, identifying waste acceptance criteria, accepting waste, establishing appropriate shipping and manifest requirements, and providing technical review of the Title II design packages and this removal action work plan (RAWP). Transportation of radioactively contaminated waste to ORNL will be arranged by ORNL's Transportation Operations Management Section. Energy Systems will also integrate project cost and scheduling into the appropriate ER management reporting system.

\subsection{MK-F}

MK-F will provide construction services using MK-F direct-hire forces and specialty subcontractors in accordance with the drawings, technical specifications and applicable DOE guidance. This will include construction planning, procurement, construction management, and construction required to implement the design. MK-F will also have lead responsibility for health and safety at the job site. 


\section{OVERVIEW OF REMOVAL ACTION}

\subsection{DESIGN}

The design of this project was performed in accordance with standard engineering practice. Drawings were prepared using the Intergraph computer-aided design system. Specifications were prepared in Construction Specifications Institute format. The design was prepared in accordance with all DOE orders. Design started on August 24, 1994, and ended certified-for-construction (issued) on November 4, 1994.

Input for the design was received from MK-F, Energy Systems, and DOE. The locations of existing site features were derived from the ORNL Atlas Drawings maintained by Energy Systems. MK-F reviewed the design package and prepared comments for Foster Wheeler. DOE provided overall direction and project management throughout the design process. The project organization is shown on Figure 2.

\subsection{PROCUREMENT}

MK-F will provide procurement services for all materials required for the construction as detailed in the design documents. Procurement activities shall be performed in accordance with DOE procedures. Items shall be procured in a timely fashion in order to prevent procurement related construction delays. All materials shall be in accordance with the design specifications for this project.

\subsection{MOBILIZATION}

MK-F shall mobilize to the site the equipment and personnel necessary to complete the construction in a safe and timely manner. MK-F shall coordinate the location of on-site support and operating facilities, as well as work areas, with the Facility Manager. Components identified for advance procurement shall be ordered in a timely fashion to support the construction schedule. Health and Safety personnel shall be working at the site during mobilization.

\subsection{CONSTRUCTION}

The location of all underground utilities shall be verified in the field before any excavation is started. After this has been done and once erosion control measures are in place, excavation can begin. Excavation shall be protected by shoring, bracing, sheet piling, underpinning, or other methods required to prevent cave-in of loose soil into excavation. Protection shall be in accordance with Occupational Safety and Health Administration regulations 29 CFR 1926, Subpart P-Excavations, latest revision. The pipe shall be kept free from soil or debris and shall be installed in accordance with the specifications. Backfill shall be placed carefully so as not to damage the pipe. The backfill shall be compacted to the specified density. Seeding will closely follow the completion of backfilling. All construction shall be performed in accordance with the drawings, specifications, and all project health and 


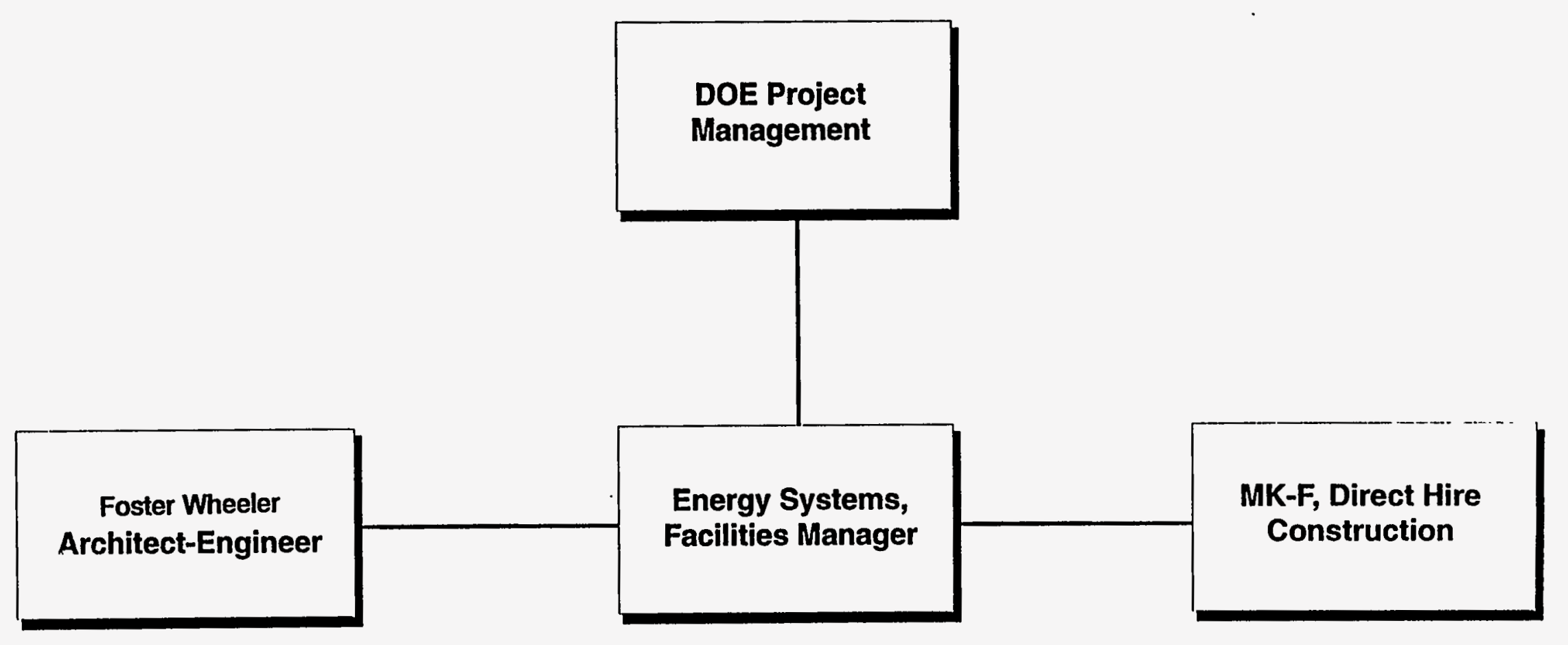


safety plans and procedures. Construction will run from November 28, 1994, to April 29, 1995, with the collection and pumping system to be operational by March 31, 1995.

\subsection{DECONTAMINATION PROCEDURES}

Decontamination procedures are addressed in detail within the project health and safety plan.

\subsection{DEMOBILIZATION}

Demobilization will take place following the completion of construction activities. The site shall be left free of trash and debris. All temporary facilities and controls shall be removed.

\subsection{POSTCONSTRUCTION REPORT}

The Postconstruction Report will be prepared by the Energy Systems Title III Representative. The report will summarize the completed construction activities. Input will be provided by Foster Wheeler as required by the Title III test order. 


\section{BIBLIOGRAPHY}

BNI (Bechtel National, Inc.) 1992. Site Characterization Summary Report for Waste Area Grouping 1 at Oak Ridge National Laboratory, Oak Ridge, Tennessee, DOE/OR-1043/V1, Bechtel National, Inc., Oak Ridge, Tenn.

Engineering Evaluation/Cost Analysis for the Waste Area Grouping 1 Corehole 8 Removal Action at the Oak Ridge National Laboratory, Oak Ridge, Tennessee, DOE/OR/02-1303\&D0, U.S. Department of Energy.

System Requirements Document for the Core Hole 8 Ground Water Removal Action in Waste Area Grouping 1 at Oak Ridge National Laboratory, Oak Ridge, Tennessee, ORNL/ER-262. Energy Systems, Oak Ridge, Tennessee. 
Appendix A

Project Participant/Responsibility Assignment Matrix 


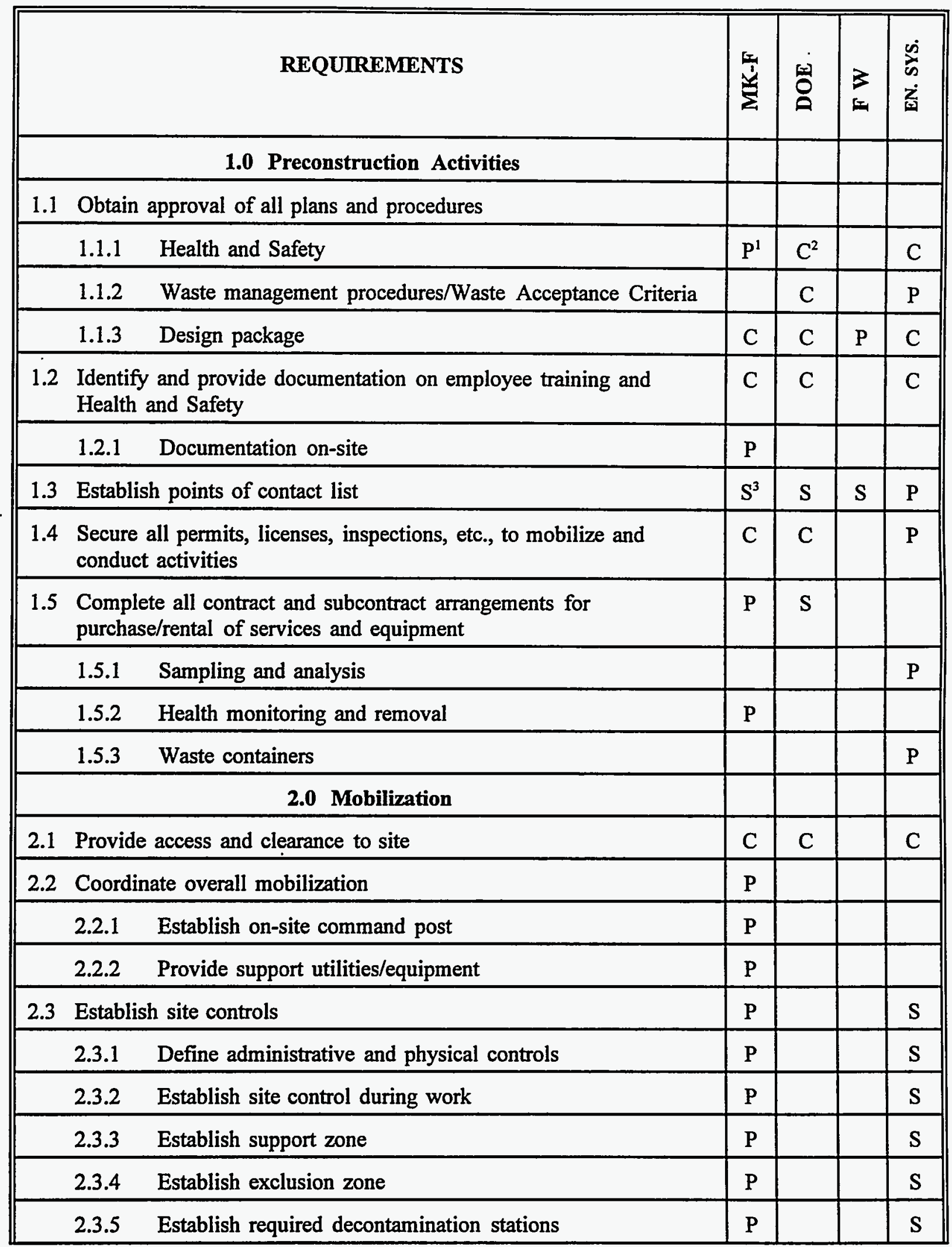




\begin{tabular}{|c|c|c|c|c|}
\hline REQUIREMENTS & 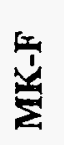 & 빙 & 3 & $\begin{array}{l}\dot{2} \\
\dot{n} \\
\dot{n} \\
\dot{2}\end{array}$ \\
\hline 2.3.6 Establish waste storage area & $\mathrm{P}$ & & & $\mathrm{S}$ \\
\hline \multicolumn{5}{|l|}{ 3.0 Site Preparation } \\
\hline 3.1 Establish erosion controls & $\mathbf{P}$ & & & 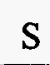 \\
\hline 3.2 Verify location of existing utilities & $\mathbf{P}$ & & & S \\
\hline \multicolumn{5}{|l|}{ 4.0 General Construction } \\
\hline 4.1 Modify existing catch basins & $\mathbf{P}$ & & & $\mathrm{S}$ \\
\hline 4.2 Install gravity pipe & $\mathbf{P}$ & & & $S$ \\
\hline 4.3 Construct pump station & $\mathbf{P}$ & & & S \\
\hline 4.4 Install force main & $\mathbf{P}$ & & & $S$ \\
\hline 4.5 Test new systems & $\mathbf{P}$ & & & $S$ \\
\hline \multicolumn{5}{|l|}{ 5.0 Waste Handling, Packaging, Marking, and Disposal } \\
\hline $\begin{array}{l}\text { 5.1 Discuss requirements with Environmental Restoration and Waste } \\
\text { Management }\end{array}$ & $\mathrm{C}$ & & & $\mathrm{C}$ \\
\hline 5.2 Containerize and stage waste on-site & $\mathbf{P}$ & & & \\
\hline 5.3 Evaluate rad contaminated soil as needed & $\mathbf{P}$ & & & \\
\hline 5.4 Package and label waste & $\mathrm{P}$ & & & $\mathrm{C}$ \\
\hline 5.5 Disposal of all packaged wastes & & & & $\mathbf{P}$ \\
\hline \multicolumn{5}{|l|}{ 6.0 Decontamination and Disposal Procedures } \\
\hline 6.1 Decon excavation equipment as needed & $\mathbf{P}$ & & & \\
\hline 6.2 Decon sampling equipment as needed & $\mathbf{P}$ & & & \\
\hline 6.3 Collect and containerize all decon waste & $\mathrm{P}$ & & & $\mathrm{C}$ \\
\hline 6.4 Disposal of decon wastes & & & & $\mathbf{P}$ \\
\hline \multicolumn{5}{|l|}{ 7.0 Waste Shipment } \\
\hline $\begin{array}{l}\text { 7.1 Define requirements for characterization, inspection, packaging, } \\
\text { delivery, and storage by approving work package }\end{array}$ & & & & $\mathbf{P}$ \\
\hline \multicolumn{5}{|l|}{ 8.0 Site Restoration } \\
\hline $8.1 \mathrm{Seed} / \mathrm{Mulch}$ & $\mathbf{P}$ & & & $\mathbf{S}$ \\
\hline 8.2 Paving & $\mathrm{P}$ & & & $\mathrm{S}$ \\
\hline
\end{tabular}


A-3

\begin{tabular}{|c|c|c|c|c|}
\hline REQUIREMENTS & 㞵 & 덩 & $B$ & $\begin{array}{l}\text { D } \\
\text { t. } \\
\text { i }\end{array}$ \\
\hline \multicolumn{5}{|l|}{ 9.0 Demobilization } \\
\hline 9.1 Complete final equipment surveys and decon & $\mathrm{P}$ & & & $\mathrm{s}$ \\
\hline 9.2 Containerize any items above releasability & $\mathbf{P}$ & & & $\mathrm{s}$ \\
\hline \multicolumn{5}{|l|}{ 10.0 Post Construction Report } \\
\hline 10.1 Prepare postconstruction report & & & $\mathrm{s}$ & $\mathbf{P}$ \\
\hline
\end{tabular}

${ }^{1} \mathbf{P}=$ Primary Responsibility

${ }^{2} \mathrm{C}=$ Co-Responsibility

${ }^{3} \mathrm{~S}=$ Secondary Responsibility 


\section{DISTRIBUTION}

1. T. M. Bonine

2. H. L. Boston

3. W. D. Brickeen

4. R. R. Lee

5-6. P. T. Owen

7. P. A. Schrandt

8. C. A Taylor

9. P. S. Wood

10. Central Research Library

11-13. Central ER Doc. Mgmt. Center

14-16. ORNL Doc. Mgmt. Center-RC

17. Laboratory Records Department

18. ORNL Patent Section

19. M. H. Bowers, Foster Wheeler Environmental Corporation, 11 Union Valley Rd., Oak Ridge, TN 37830

20. G. R. Hudson, DOE Oak Ridge Operations Office, P.O. Box 2001, Oak Ridge, TN 37831-8541

21. W. I. Rogerson, MK-Ferguson of Oak Ridge Company, P.O Box 2000, Oak Ridge, TN 37831

22. T. R. Sigmon, MK-Ferguson of Oak Ridge Company, P.O Box 2000, Oak Ridge, TN 37831

23. J. T. Sweeney, DOE Oak Ridge Operations Office, P.O. Box 2001, Oak Ridge, TN 37831-8541

24-25. Office of Scientific and Technical Information, P.O. Box 62, Oak Ridge, TN 37831 